\title{
Isolation and characterization of biogenic calcium carbonate/phosphate from oral bacteria and their adhesion studies on YSZ-coated titanium substrate for dental implant application
}

\author{
GOBI SARAVANAN KALIARAJ*, KAMALAN KIRUBAHARAN, G PRADHABAN, \\ P KUPPUSAMI and VINITA VISHWAKARMA \\ Centre for Nanoscience and Nanotechnology, Sathyabama University, Chennai 600119, India
}

MS received 13 October 2015; accepted 29 October 2015

\begin{abstract}
Biogenic calcium carbonate/phosphate were isolated and characterized from oral bacteria (CPOB). The crystalline nature and morphology of calcium carbonate/phosphate were characterized by X-ray diffraction (XRD) and field emission scanning electron microscopy (FESEM), respectively. XRD analysis revealed the cubic phase of YSZ coating as well as biogenic calcium carbonate (rhombohedral) and calcium phosphate oxide (hexagonal) was observed from CPOB. FESEM confirmed the extracellular synthesis of calcium compounds. Bacterial adhesion result reveals that YSZ coating drastically reduce bacterial invasion than titanium substrate.
\end{abstract}

Keywords. Oral bacteria; bioceramic; dental implant; YSZ coating; epifluorescence microscopy.

\section{Introduction}

Titanium (Ti) and its alloys are widely used as crown or teeth (bridge or denture) in orthodontic implants because of its mechanical strength, corrosion resistance and low allergenicity [1]. Especially, commercially pure Ti has higher ductility than the triphasic alloy Ti-6Al-4V. However, microbial invasion on implant substrate is highly challengeable in oral environment, acting as a potential reservoir for microbial growth resulting in persistent infections and failure [2]. Further, pure $\mathrm{Ti}$ surface susceptible to ductility with low shear resistance due to native oxide present on the Ti surface which will improve the surface roughness [3], favours bacterial attachment and subsequent infection. Initial bacterial attachment and subsequent colonization play important roles which decide the implant's durability. Some bacteria (S. oralis, S. salivarius, S. mitisx etc.) secrete calcium-based compounds in oral environment and deposit on host surface or an implanted devices (dentures, dental abutments, etc.). The attached bacteria produce slightly acidic $\mathrm{pH}$ environment [4], which will cause dissolution of tooth enamel as well as implant surfaces and leads to periodontis, caries, periimplantitis and implant failure [5].

Hence, surface modification through bioceramic materials for dental applications has been remarkably effective for the past few decades to avoid the bacterial invasion. Dental bioceramics are classically in demand due to their chemical inertness and allowing for excellent esthetics. Due to the superior mechanical properties of partially stabilized zirconia, it has been used for dental markets as ceramic posts,

\footnotetext{
*Author for correspondence (gsbiotech5@gmail.com)
}

abutments and femoral heads for total hip replacements and dental implants [6]. Kargianni et al [7] reported that biomaterial coated with zirconia effectively reduced initial bacterial adhesion against E. faecalis, S. aureus and C. albicans [7]. Hence, the present study is to isolate CPOB and their initial attachment and antimicrobial behaviour on YSZ-coated and uncoated Ti substrate.

\section{Experimental}

\subsection{Deposition of YSZ coatings and microstructural characterization}

$10 \mathrm{~mol} \% \mathrm{YSZ}$ was pelletized, sintered at $1450^{\circ} \mathrm{C}$ and deposited onto mirror-polished pure titanium by electron beam evaporation (PLASSYS MEB600, Marolles-en Hurepoix, France) with an accelerating voltage of $8 \mathrm{kV}$ at $673 \mathrm{~K}$ substrate temperature. Base pressure was about $8 \times 10^{-4} \mathrm{~Pa}$ and the distance between source material and substrate was $630 \mathrm{~mm}$.

XRD was used to characterize the deposited film in a Rigaku (Smart Lab 9KW) diffractometer using a copper $\mathrm{K} \alpha$ $(\lambda=1.5418 \AA)$ radiation source. Surface topography of the samples was analysed by AFM using SLOVER PRO manufactured by M/s NTMDT, Apeldoorn, the Netherlands. Cross-sectional analysis of coating was observed using FESEM (Supra 55, Carl-Zeiss, Jena, Germany).

\subsection{Isolation and partial biochemical identification of bacteria}

Scales (dental calculus) were scrapped from tooth enamel of six healthy volunteers and $0.1 \mathrm{~g}$ of collected samples were 
transferred to $9 \mathrm{ml}$ of sterilized $1 \%$ peptone water and finally subjected to serial dilution and plated by using B4 medium ( $\left(\mathrm{g} \mathrm{l}^{-1}\right)$ : calcium acetate 2.5 ; yeast extract 4.0 ; glucose 10.0$)$ [8] and incubated at $37^{\circ} \mathrm{C}$ for $48 \mathrm{~h}$. Bacterial isolates were subjected to identify upto genus level according to Bergey's Manual of Determinative Bacteriology [9] using Himedia biochemical test kit.

\subsection{Bacterial attachment studies}

A volume of $0.4 \mathrm{ml}$ of biochemically identified CPOB culture was transferred to $20 \mathrm{ml} \mathrm{B} 4$ broth and incubated for $3 \mathrm{~h}$ at $37^{\circ} \mathrm{C}$ with $110 \mathrm{rpm}$. Then, the bacterial culture was adjusted to get final concentration of about $3 \times 10^{5}$ colony forming units $\mathrm{ml}^{-1}\left(\mathrm{CFU} \mathrm{m}{ }^{-1}\right)$. Finally, the bacterial samples were inoculated into sterilized YSZ-coated and uncoated Ti substrates containing standard fusayama artificial saliva solution with yeast extract [10] for $6 \mathrm{~h}$ to enumerate initial attachment behaviour. After incubation, the bacterial samples

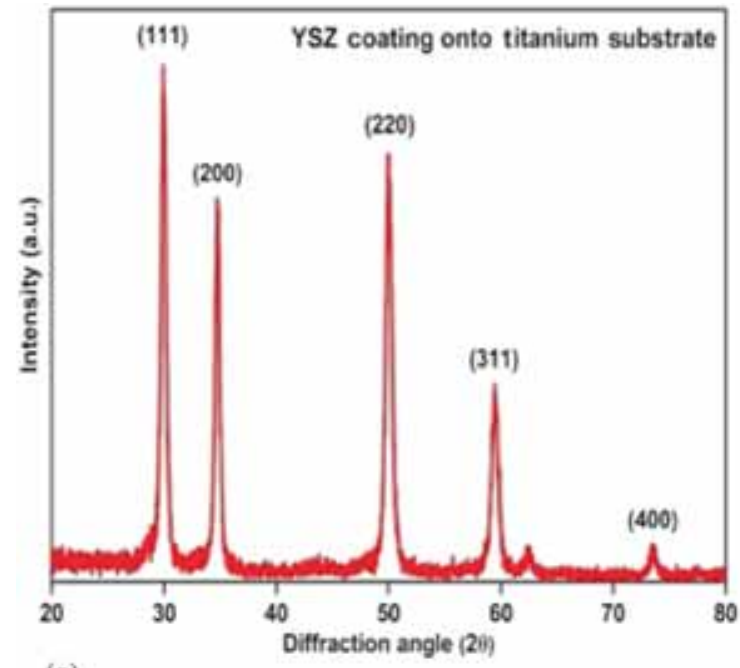

(a)

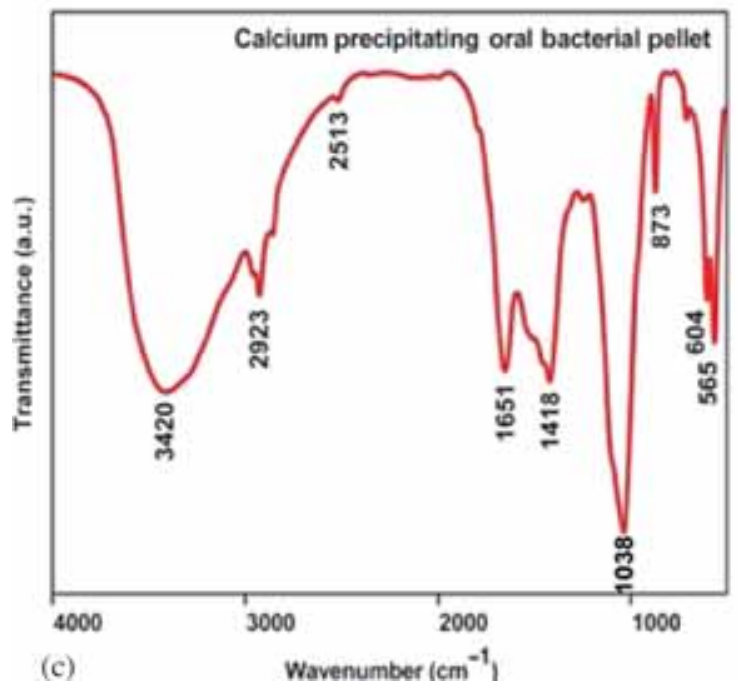

were subjected to serial dilution followed by agar plating, incubated at $37^{\circ} \mathrm{C}$ for $24 \mathrm{~h}$ for total viable count analysis

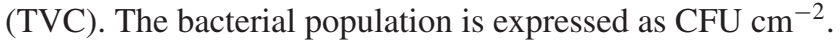

2.3a Antimicrobial studies: $100 \mu \mathrm{l}$ of CPOB was added drop-wise onto test samples and laid at ambient temperature for $6 \mathrm{~h}$. After incubation, cells were dyed with acridine orange $(\mathrm{AO})$, then rinsed with deionized water [11] and imaged using epifluorescence microscopy to calculate antimicrobial efficiency by live/dead cell analysis as follows,

$$
R=\frac{B-A}{B} \times 100(\%),
$$

where, ' $B$ ' and ' $A$ ' are number of orange fluorescence bacterial cells enumerated at ' 0 ' and $6 \mathrm{~h}$ (data is not shown) exposure of test samples.

Further, B4 broth containing bacterial suspension was centrifuged at $6000 \mathrm{rpm}$ for $30 \mathrm{~min}$ and dried pellet was

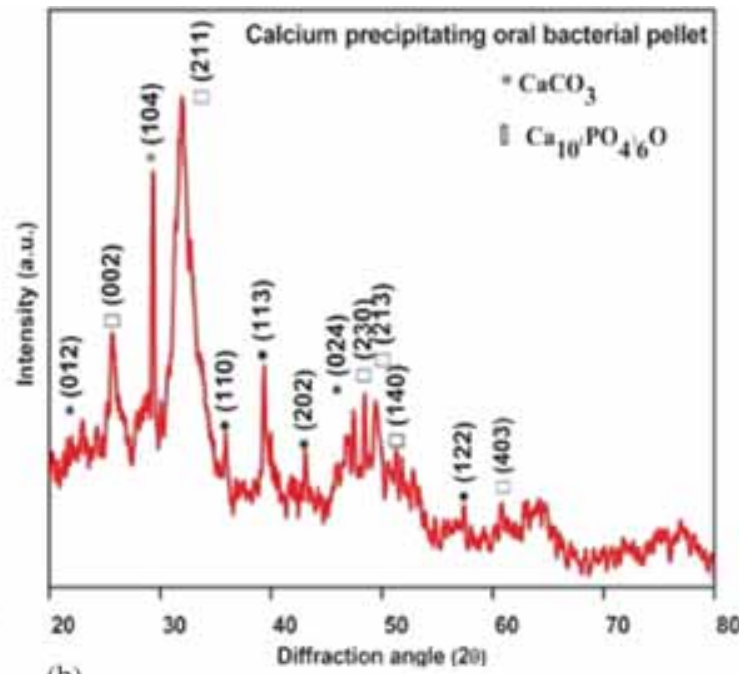

(b)

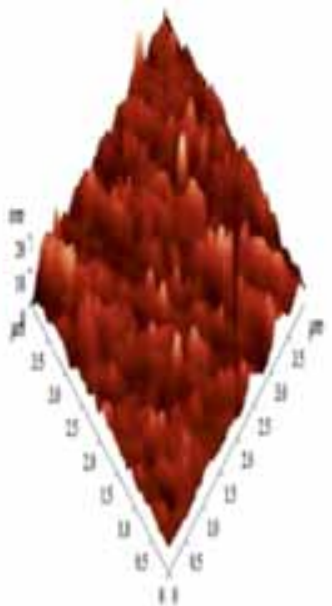

(d)

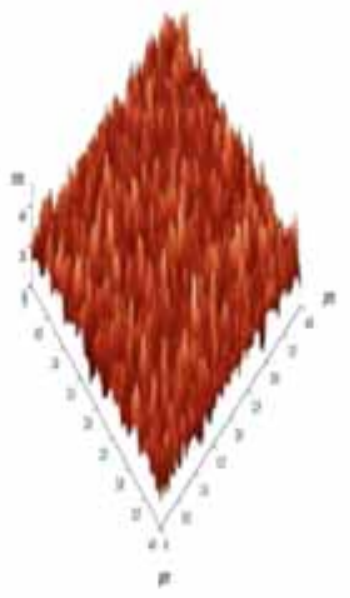

(e)

Figure 1. (a) XRD pattern of YSZ coating. (b) XRD and (c) FTIR pattern of CPOB pellet. AFM analysis of (d) uncoated Ti substrate and (e) YSZ coating. 

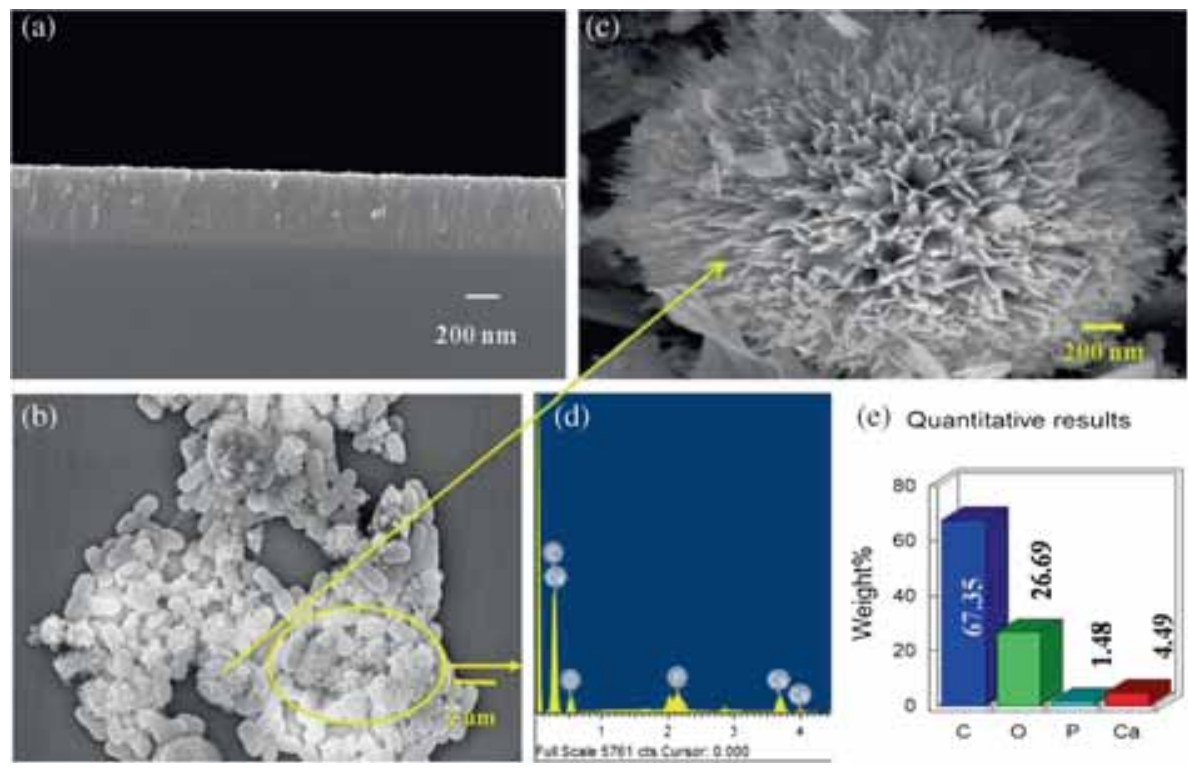

(e) Quantitative results

Figure 2. (a) SEM cross-sectional view of YSZ coating. (b) and (c) SEM images of calcite precipitation from bacterial cell wall. (d) Elemental analysis of calcium precipitation.

characterized by XRD and Fourier transform infrared (FTIR; Thermo Scientific Systems, Nicolet-6700) techniques.

\section{Results and discussions}

\subsection{Structural analysis}

Figure 1a shows diffraction pattern of YSZ coating showing the peak positions at $30.05,34.92,50.15$ and $59.64^{\circ}$ are well indexed with the cubic structure of YSZ (JCPDS no. 301468) and crystallite size was about $10 \mathrm{~nm}$ for (111) plane. The diffraction peaks (figure 1b) noticed at 29.0, 29.3, 36.0, $39.3,43.1,47.4$ and $57.3^{\circ}$ corresponded to the rhombohedral phase of calcium carbonate (JCPDS no. 89-6495) and peaks at $2 \theta=25.7,32.0,48.4,49.5,51.2$ and $60.8^{\circ}$ belonged to hexagonal phase of calcium phosphate oxide (JCPDS no. 862342) of CPOB pellet. FTIR spectra (figure 1c) of CPOB pellet showed several absorption peaks at 3420, 2923, 2513, $1651,1418,1038,873,604$ and $565 \mathrm{~cm}^{-1}$ associated with O-H group [4,12], C-H stretch (alkane compounds) [13], $\mathrm{C}=\mathrm{C}$ stretch (aromatic compound), $\mathrm{V} 3$ vibrational mode due to carbonate ions (for 1651 and $1418 \mathrm{~cm}^{-1}$ ), carboxylic dimer stretch (metallic carbonates) [13], calcium carbonate and $\mathrm{PO}_{4}^{3-}$ (for 604 and $565 \mathrm{~cm}^{-1}$ ) [12], respectively. Results revealed the presence of calcium carbonate and calcium phosphate from bacterial precipitate. Figure 1d shows AFM analysis of uncoated Ti substrate showed the average roughness $\left(R_{\mathrm{a}}\right)$ of about $4.6 \mathrm{~nm}$ due to the surface irregularities and defectness; whereas YSZ coating (figure 1e) exhibited uniform grains and smooth surface with the $R_{\mathrm{a}}$ value of $1.6 \mathrm{~nm}$.

Figure 2a shows SEM cross-sectional image of YSZ coating which reveals columnar structure with the thickness of $500 \mathrm{~nm}$. Figure $2 \mathrm{~b}$ shows extracellular calcite precipitation of
Table 1. Morphological and biochemical characteristics of calcium precipitating bacteria.

\begin{tabular}{|c|c|}
\hline Characteristics & Paenibacillus sp. \\
\hline \multicolumn{2}{|l|}{ Cell morphology } \\
\hline Gram stain & + \\
\hline \multicolumn{2}{|l|}{ Shape rod } \\
\hline Motility & + \\
\hline \multicolumn{2}{|l|}{ Biochemical reaction } \\
\hline Indole test & - \\
\hline Methyl red test & - \\
\hline V P test & - \\
\hline Citrate utilization test & - \\
\hline Oxidase test & - \\
\hline Catalase test & - \\
\hline Nitrate reduction test & - \\
\hline Triple sugar ion test & $\mathrm{AB} / \mathrm{AS}$ \\
\hline \multicolumn{2}{|l|}{ Production of acid from } \\
\hline Galactose & + \\
\hline Fructose & - \\
\hline Sucrose & + \\
\hline Lactose & + \\
\hline L-Arabinose & - \\
\hline Raffinose & - \\
\hline \multicolumn{2}{|l|}{ Hydrolysis of } \\
\hline Starch & + \\
\hline Gelatin & - \\
\hline Urea & + \\
\hline Lipase & - \\
\hline
\end{tabular}

Note: + , positive; - , negative; $\mathrm{AB} / \mathrm{AS}$, acid butt, alkaline slant. 
CPOB using SEM. Figure 2c shows the enlarged view and it shows flower-like morphology on calcite precipitation on cell wall. Further, it clearly reveals that $\mathrm{CPOB}$ undergoes extracellular calcite precipitation which constitutes (figure $2 \mathrm{~d}$ ) $\mathrm{Ca}$, $\mathrm{P}, \mathrm{O}$ elements with the wt\% of $\mathrm{Ca}, 28.52 ; \mathrm{P}, 12.69 ; \mathrm{O}, 58.8$ by elemental analysis using EDAX.

\subsection{Biochemical identification and their characterization}

Among the various dental calculus bacterial strains, Paenibacillus sp. was selected for the present study. Preliminary identification of the bacteria by biochemical test indicated that the isolates belonged to the genus Paenibacillus. The phenotypic and biochemical profiles of Paenibacillus sp. are shown in table 1.

\subsection{Bacterial attachment study}

TVC analysis exhibit more CPOB adherence on uncoated Ti substrate which might be the higher surface free energy of $\mathrm{Ti}$ $\left(\mathrm{Ti}^{3+}\right.$ and $\left.\mathrm{Ti}^{2+}\right)$ showing positive effects in initial colonization. Whereas drastic reduction of bacterial adherence was observed on YSZ coating owing to the less surface energy rather than uncoated Ti substrates as surface smoothness of the coating which hinders electrostatic interactions. The calculated TVC was found to be $1.9 \times 10^{2}$ and 80 for uncoated Ti substrate and YSZ coating, respectively.

3.3a Antibacterial studies: Figure $3 \mathrm{a}$ and $\mathrm{b}$ shows the antibacterial effect of YSZ-coated and uncoated Ti substrate. AO-treated bacteria fluoresces orange colour which
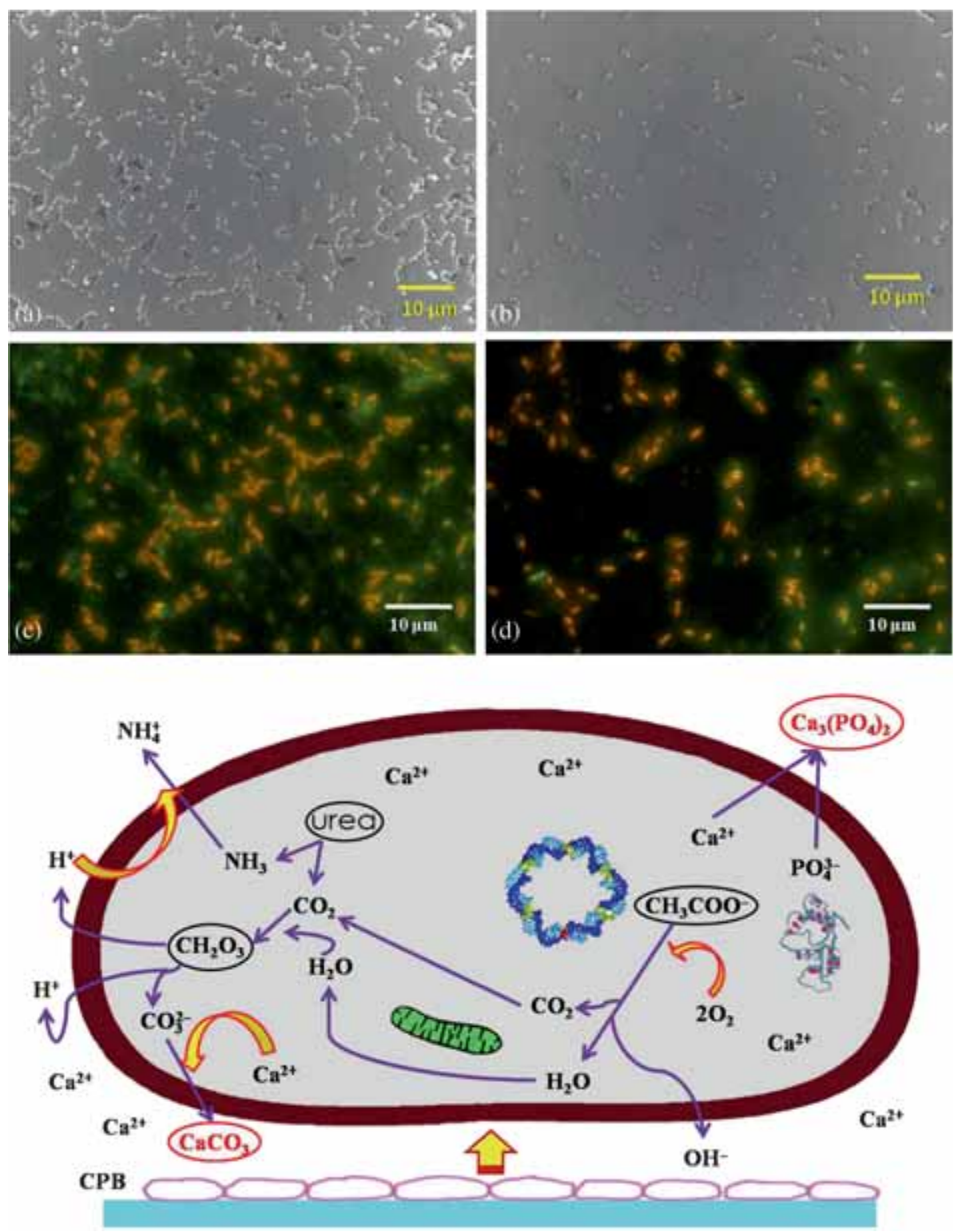

Figure 3. Epifluorescence images of $\mathrm{CPOB}$ adhesion onto (a) uncoated Ti substrate and (b) YSZ coating. (c) Schematic diagram of CPOB precipitation. 
indicates active metabolizing cells [14] on both the samples which reveals poor antibacterial property against CPOB. Antimicrobial efficiency of 3 and 5\% (data not shown) was exhibited in uncoated $\mathrm{Ti}$ substrate and YSZ coating, respectively.

Oral environment has rich source for calcification by calcium-precipitating oral bacteria through metabolic activity of the cell [15]. Figure $3 c$ shows the schematic view of calcium precipitation from the oral bacteria which constitutes three major metabolic activities to precipitate calcite on the surface of the bacterial cell wall. During the metabolic activity, $\mathrm{NH}_{3}$ released by acid hydrolysis of urea and excrete $\mathrm{NH}_{4}^{+}$ by proton consumption which generated from carbonic acid [16]. The continuous release of ammonia enhances the rate of $\mathrm{pH}$ of bacterial surroundings and triggers calcium carbonate and calcium phosphate precipitation on cell wall. Besides, the presence of minor quantity of acetate also enhances the rate of calcium deposition [12].

\section{Conclusion}

Calcium carbonate and calcium phosphate were isolated and characterized from oral Paenibacillus sp. bacteria and their adhesion studies were carried out on YSZ coating. The present study reveals that YSZ coating exhibited anti-biofouling behaviour against $\mathrm{CPOB}$, though it failed to express antibacterial performance. Hence, YSZ-modified Ti implants will obviously be a good candidature for modern dentistry.

\section{Acknowledgement}

We thank Dr Jeppiaar, Chancellor of Sathyabama University, Chennai, for his motivation and financial assistance.

\section{References}

[1] Poh C K, Shi Z, Lim T Y, Neoh K G and Wang W 2010 Biomaterials 311578

[2] Ramage G, Martinez J P and Lopez-Ribot J L 2006 FEMS Yeast Res. 6979

[3] Sovak G, Weiss A and Gotman I 2000 J. Bone Joint Surg. 82 290

[4] Dhandapani P, Murali Kannan M, Anandkumar B, Maruthamuthu S and Manoharan S P 2014 Oral Sci. Internation 1122

[5] Wolff M S and Larson C 2009 Brazilian Oral Res. 2331

[6] Andreiotelli M and Kohal R J 2009 Clin. Implant Dent. Related Res. 11158

[7] Karygianni L, Jahnig A, Schienle S, Bernsmann F, Adolfsson E, Kohal R J et al 2013 Materials 65659

[8] Baskar S, Baskar R, Mauclaire L and Mckenzie J A 2006 Curr. Sci. 9058

[9] Holt J, Kreig N and Sneath P 1994 Bergey's Manual of Determinative Bacteriology (Maryland, USA: Lippincott Williams \& Wilkins)

[10] Laurent F, Grosgogeat B, Reclaru L, Dalard F and Lissac M 2001 Biomater. 222273

[11] Vishwakarma V, Josephine J, George R P, Krishnan R, Dash S, Kamruddin M et al 2009 Biofoul. 25705

[12] Maruthamuthu S, Dhandapani P, Ponmariappan S, Sathiyanarayanan S, Muthukrishnan S and Palaniswamy N 2010 J. Fail. Analysis Prevent 10416

[13] Rehman I and Bonfield W 1997 J. Mat. Sci.: Mat. Med. 81

[14] Evans 2005 Biofilms: recent advances in their study and control (United Kingdom: Harwood Academic Publishers)

[15] McConnaughey T A and Whelan F F 1997 Earth Sci. Rev. 42 95

[16] Fujita Y, Ferris E G, Lawson R D, Colwell F S and Smith R W 2000 Geomicrobiol. J. 17305 